\section{US cuts back on official exchanges with USSR}

THE US scientific community has been almost unanimous in condemning recent moves by the government of the USSR, in the occupation of Afghanistan and the internal exile of physicist Andrei Sakharov.

But while many support the legitimacy of individual protest, there remains uncertainty over how far official reaction should undermine the network of bilateral exchange agreements which have, in recent years, begun to produce mutual benefits.

On the one hand, Congressman George Brown, last week introduced a bill calling for a one-year moratorium on US-Soviet exchange except those essential to national needs or a matter of extraordinary circumstance of individual conscience.

The Carter administration, however, while keen to make clear to the Soviet government that it is not 'business as usual' for scientific exchanges, is also concerned to maintain what it can of the existing framework for scientific cooperation.

Thus all high-level meetings between scientists and scientific administrators from the two sides are being deferred. Three such meetings have already been postponed since the occupation of Afghanistan, and all current exchange arrangements are undergoing close review.

But the administration is at present keeping the door open for low-level contacts between scientists which it considers to have a purely scientific or humanitarian purpose. For example, a scientific delegation from the USSR studying the biological control of pests has been allowed in - but a delegation coming from the USSR to discuss science policy has not, since it was lead by a deputy minister.

The administration's determination to keep open channels of communication, even if limiting activities in these channels, was supported by Academy President Dr Philip Handler, who will be leading the US delegation to the scientific forum in Hamburg later this month to discuss the progress of the Helsinki accords of 1975. But he emphasised the Academy's position that the main responsibility lay on the shoulders of individual scientists.

Uncertainty over how tough the administration should be is reflected in the debate over what type of strategy the US delegation should pursue at the Hamburg science forum.

Few currently support a complete boycott of the meeting. And there seems general agreement that human righs considerations are central to international scientific communication and exchange.

But given agreement that the forum should discuss, in Dr Press's words, "the context within which scientific cooperation takes place, not simply those scientific subjects which are amply discussed in many other settings", opinions are divided on what such discussions should aim.

Dr Paul J Flory, for example, Emeritus Professor of Chemistry at Stanford University and a member of the US delegation, suggested that the scientific community should "reshape its criteria for participation" and lay down a set of minimum conditions for future international collaboration.

These might include the condition that "negotiations should be in the hands of scientists, not governments", and that participants be selected "without regard for their political conformity, race or ethnic background".

Others have suggested more modest goals. In particular Dr John T Edsall of Harvard University, chairman of the American Association for the Advancement of Sciences' Committee on Scientific Freedom and Responsibility, has suggested that the forum should establish a working group to collect and review reports about obstacles to international scientific cooperation.

David Dickson

\title{
Soviet Union responds to western reaction
}

WITHIN a few minutes of the news of Sakharov's exile reaching the West, the Royal Society sent a cautious telegram to the Soviet Academy of Sciences, deploring the action and asking for the Academy's comment. Six days later, the Academy made its opinion known in a formal statement by the Presidium.

The statement condemned the activities of Academician Sakharov as being directed "against the interests of our country and the Soviet people, actions that help to build up international tension and bring into disrepute the exalted title of Soviet scientist". Ironically, the Presidium's statement accuses Sakharov of "undermining" precisely those ideals of peace, arms limitation and detente that underlie his whole involvement with human rights. Last year, indeed, he spoke
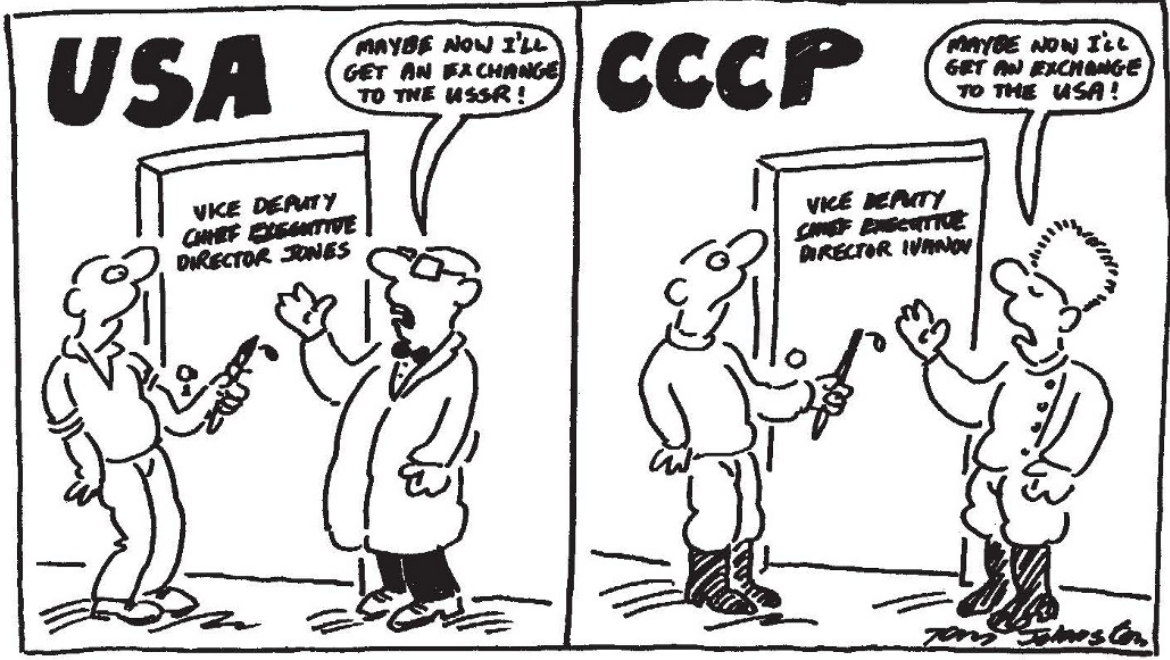

out resolutely against overenthusiastic efforts to link US willingness to sign SALT-2 with human rights in the USSR.

Nevertheless, the statement contained no indications that moves would be made to expel Sakharov from the Academy. While feelings of solidarity may so far have prevented Sakharov's fellowAcademicians from expelling him from their ranks, there is little doubt that scientists of dissident outlook and lesser prestige now feel themselves under increasing threat. Andrei Tverdokhlebov, the young physicist, who had formerly worked closely with Sakharov in the human rights movement was expelled to the West just in time to testify before last week's congressional hearing in preparation for the Hamburg scientific forum. And a number of Jewish refusniks, notably Naum Meiman the mathematician and Aleksandr Lerner the cybernetician, have expressed fears for their own liberty.

Meanwhile, the Soviet authorities are attempting to counter western concern by denying that Sakharov has been, in any sense, exiled. "Administrative banishment", said one Tass statement "is neither 'arrest' nor 'exile'." Gor'kii, said comentator Yaroslav Khabarov on the foreign service of Moscow radio, "is one of the most beautiful towns in Russia, as well as a major industrial, cultural, and scientific centre with its own university". By simply stripping Sakharov of his awards and titles, and "moving him outside the city of Moscow", Khabarov explained, Sakharov has been given "the opportunity to continue to work in keeping with his profession"

Vera Rich 